\title{
Treatment of wheat straw using tannase and white-rot fungus to improve feed utilization by ruminants
}

\author{
Shailendra Raghuwanshi, Swati Misra and Rajendra Kumar Saxena*
}

\begin{abstract}
Background: Current research to enrich cattle feed has primarily focused on treatment using white rot fungi, while there are scarce reports using the enzyme tannase, which is discussed only in reviews or in the form of a hypothesis. In this context, the aim of the present study was to evaluate the effect of tannase on wheat straw (WS) and also the effect of lyophilized tannase at concentrations of $0.1 \%, 0.2 \%$, and $0.3 \%(\mathrm{~W} / \mathrm{W})$ on WS followed by fermentation with Ganoderma sp. for $10 \mathrm{~d}$ and compared in relation to biochemical parameters, crude protein (CP) content, and nutritional value by calculating the $\mathrm{C} / \mathrm{N}$ ratio in order to improve the nutritional value of cattle feed.

Results: Penicillium charlesii, a tannase-producing microorganism, produced $61.4 \mathrm{IU} / \mathrm{mL}$ of tannase in $54 \mathrm{~h}$ when $2 \%$ $(\mathrm{w} / \mathrm{V})$ tannic acid (TA) was initially used as a substrate in medium containing (\% w/v) sucrose (1.0), $\mathrm{NaNO}_{3}(1.0)$, and $\mathrm{MgSO}_{4}(0.08 \mathrm{pH}, 5.0)$ in a 300-L fermentor (working volume $220 \mathrm{~L}$ ), and concomitantly fed with $1.0 \%(\mathrm{~W} / \mathrm{V}) \mathrm{TA}$ after $24 \mathrm{~h}$. The yield of partially purified and lyophilized tannase was $5.8 \mathrm{IU} / \mathrm{mg}$. The tannin-free myco-straw at $0.1 \%$ $(\mathrm{w} / \mathrm{w})$ tannase showed $37.8 \%(\mathrm{w} / \mathrm{W})$ lignin degradation with only a $20.4 \%(\mathrm{~W} / \mathrm{W})$ decrease in cellulose content and the in vitro feed digestibility was $32.2 \%$. An increase in CP content (up to 1.28-fold) along with a lower C/N ratio of $25.0 \%$, as compared to myco-straw, was obtained.
\end{abstract}

Conclusions: The use of tannin-free myco-straw has potential to improve the nutritional content of cattle feed. This biological treatment process was safe, eco-friendly, easy to perform, and was less expensive as compared to other treatment methods.

Keywords: Ganoderma sp, High energy cattle feed, Tannase, Tannin free myco-straw

\section{Background}

The drastic increase in human population has caused intensified pressure on agricultural land use, which has led to the conversion of farmland into commercial landscapes. Therefore, countries with agriculture-based economies have endured economic constraints that have negatively impacted the health of cattle due to nutritional deficiencies of feed. Therefore, it is of the utmost importance to improve the quality of cattle feed so that it can be easily be digested by ruminants; therefore, producing higher milk yields to benefit the ever-increasing demand for milk and milk products. Therefore, to overcome problems associated with the decrease in available

\footnotetext{
* Correspondence: rksmicro@yahoo.co.in

Department of Microbiology, University of Delhi South Campus, Benito Juarez Road, New Delhi 110 021, India
}

farmland and the increased demand for milk and milk products, efforts are being made to reduce the wide gap between the requirement and availability of feed and fodder, including technological interventions to increase yield, expand areas to raise fodder crops, conserve land for growing feed and fodder, improve the nutritional value of poor quality roughages, and develop unconventional feeds at competitive prices [1]. The main focus of cattle feed research has been on the enhancement of the nutritional value of dry roughages using physical, chemical, and biological treatments [2].

Globally, India is the second largest producer of wheat as a cereal crop, which, incidentally, produces a large amount of crop residue. Apart from feed and fodder production, a very limited amount of wheat straw (WS) is used for various other purposes such as the manufacture of ethanol, paper, and fertilizer, while the majority is 
either removed from the field, burned on site, piled, spread over fields, or used as mulch [3]. However, the burning of straw causes atmospheric pollution, although it is a cost-effective disposal method [4]. Although the use of WS for ruminant feeding is constrained by its low digestibility of the energy-rich cell walls because of the high silica content, the tannins, lignin, and the relatively low protein and energy content, when fed to cattle as the only feed source it could significantly influence livestock production $[5,6]$.

Several physical and chemical treatments have been proposed to improve the degradability of WS and subsequent feed intake by cattle. Still, the practical use of these treatments is restricted by safety concerns, cost, and potentially negative environmental impacts [7]. In this respect, an alternative approach is the use of ligninolytic fungi or their enzymes to shorten the incubation period and reduce the use of potentially toxic chemicals [3]. Enzymatic and biological delignification has an edge over other treatment methods to improve the nutritional value of WS, as it includes mild reaction conditions, avoids the use of toxic and corrosive chemicals, produces higher product yield, and has fewer side reactions, lower energy demand, and less reactor resistance [8-10]. For biological delignifiaction, white rot fungi (WRF), a type wood-decaying basidiomycetes, act as lignocellulolytic microorganisms, which contains a group of enzymes of varied functions, including the hydrolytic enzymes cellulase and xylanases that degrade polysaccharides and oxidative ligninolytic enzymes such as lignin peroxidase, manganese peroxidase $(\mathrm{MnP})$, and laccase that degrade lignin. Several WRF species are effective lignin degraders that can be exploited to improve the nutritional value of fodder for ruminant nutrition without compromising the cellulose and hemicellulose constituents [11-13].

Tannin acyl hydrolase, commonly referred to as tannase (E.C. 3.1.1.20), is produced by various micro-organisms, and has been reported to improve the nutritional value of feed by the degradation of tannins. It is also able to hydrolyze ester bonds (i.e., the galloyl ester of an alcohol moiety), as well as depside bonds (the galloyl ester of gallic acid, GA) of substrates (or complex polyphenols) such as tannic acid (TA), epicatechin gallate, epigallocatechin gallate, and chlorogenic acid [14]. The breakdown of complex polyphenols could lead to production of GA, epicatechin, epicatechin gallate, and glucose [15]. To date, studies on feed enrichment have mainly focused on treatment using WRF, whereas reports using tannases remain scarce and are presented only in reviews or in the form of hypotheses.

In the present study, the effect of tannase-treatment on WS subjected to fungal pellet inoculum of Ganoderma spp. was examined and compared in relation to biochemical parameters and crude protein $(\mathrm{CP})$ production to improve the nutritional value of cattle feed, as evaluated by the carbon-to-nitrogen $(\mathrm{C} / \mathrm{N})$ ratio.

\section{Materials and methods \\ Chemicals and reagents}

All chemicals used in this study were of commercial/analytical reagent grade and purchased from Sisco Research Laboratories Pvt., Ltd. (Mumbai, India), Central Drug House Pvt., Ltd. (Mumbai, India) or SS Fermozyme Pvt. Ltd. (New Delhi, India).

\section{Estimation of tannase content}

The spectrophotometric method described by Deschamps et al. [16] was used to estimate tannase activity. One IU of tannase was defined as the amount of enzyme required to release $1.0 \mu \mathrm{mol}$ of $\mathrm{GA} / \mathrm{mL}$ of the substrate in $1 \mathrm{~min}$ under the specific assay conditions.

\section{Estimation of residual TA content}

The remaining TA content in the fermented broth was estimated using the methods of Hagerman and Butler [17] and expressed as a percentage of the initial concentration. The effect of partially purified and lyophilized tannase on the nutritional value of cattle feed (WS) was evaluated.

\section{Application of tannase to improve the nutritional value of cattle feed (WS) \\ Preparation of tannin-free WS}

Pre-dried WS was treated with different concentration of tannase $(0.1 \%-0.3 \%(\mathrm{w} / \mathrm{w})$ with an activity of $5.8 \mathrm{IU} /$ $\mathrm{mg}$ ) to remove tannins. Briefly, lyophilized tannase was dissolved in citrate phosphate buffer and sprayed on WS to obtain a moisture ratio of 1:2 (WS: moisture) and then mixed, incubated at $40^{\circ} \mathrm{C}$ under static conditions for $6.0 \mathrm{~h}$, and analyzed for remaining tannin content.

The untreated and enzyme-treated WS samples were powdered using a laboratory mill (Remi Motors, Delhi, India) and sieved (30 mesh, $0.5 \mathrm{~mm}$ ) for analytical purposes. After enzyme treatment, the WS was considered tannin-free.

\section{Experimental organisms and inoculum preparation}

Ganoderma spp. obtained from a laboratory stock culture collection (isolated from the bark of Eucalyptus lanceolate from the forested area near Delhi, India), were maintained on malt extract agar (MEA), containing $(\mathrm{g} / \mathrm{L})$ malt extract, 20.0; $\mathrm{KH}_{2} \mathrm{PO}_{4}, 0.5 ; \mathrm{MgSO}_{4} \bullet 7 \mathrm{H}_{2} \mathrm{O}, 0.5$; $\mathrm{Ca}\left(\mathrm{NO}_{3}\right)_{2} \cdot 4 \mathrm{H}_{2} \mathrm{O}, 0.5$; and agar, $20.0(\mathrm{pH} 5.5)$, at $30^{\circ} \mathrm{C}$. The obtained culture was stored at $4{ }^{\circ} \mathrm{C}$ and subcultured every 2 wk. A $250-\mathrm{mL}$ Erlenmeyer flask containing $50 \mathrm{~mL}$ of sterile malt extract broth (MEB) was inoculated with two mycelial discs (8 $\mathrm{mm}$ in diameter) from the periphery of 7 
d-old fungal cultures grown on MEA. The inoculum was incubated at $30^{\circ} \mathrm{C}$ for $5 \mathrm{~d}$ under static conditions. The obtained mycelial mat was further homogenized and then inoculated $(4 \% \mathrm{v} / \mathrm{v})$ in $2-\mathrm{L}$ Erlenmeyer flasks containing $500 \mathrm{~mL} \mathrm{MEB}$ and incubated at $30^{\circ} \mathrm{C}$ for $5 \mathrm{~d}$ in a rotary incubator at $200 \mathrm{rpm}$. The fungal mass, obtained in the form of pellets, was separated from the culture broth through filtration using pre-weighed Whatman grade no. 1 filter paper. The formed pellets were used as inocula for further experiments. After being thoroughly washed with deionized water, dried at $55^{\circ} \mathrm{C}$ until a constant mass was achieved, and weighed.

\section{Solid state fermentation}

Enamel trays $(40 \mathrm{~cm} \times 32 \mathrm{~cm} \times 7.5 \mathrm{~cm})$ were loaded with $500 \mathrm{~g}$ of tannin-free or untreated WS (as a control) and moistened with mineral salt solution and sterilized. Each sterilized tray was inoculated with a dry fungal mass of $3.75-4.00 \mathrm{~g}(0.75 \% \mathrm{w} / \mathrm{w})$. Sterile mineral salt solution was added to the trays to obtain a final substrateto-moisture ratio of $1: 3$ and incubated at $30^{\circ} \mathrm{C}$ under $60 \%$ relative humidity for $10 \mathrm{~d}$. Following incubation, the trays were harvested to determine production of various enzymes and the proximate and chemical composition of the WS. All experiments were performed in three times.

\section{Enzyme assays}

The myco-straw (WS, both enzymatically treated and non-treated, along with fungal mycelium; $5 \mathrm{~g}$ of wet weight) was removed aseptically from the flasks after incubation for $10 \mathrm{~d}$ and then suspended in $20 \mathrm{~mL}$ of acetate buffer $(20 \mathrm{mmol} / \mathrm{L}, \mathrm{pH} 5.0)$ and agitated at $200 \mathrm{rpm}$ for $1 \mathrm{~h}$. The extrudates were pressed through a muslin cloth to maximize enzyme extraction and centrifuged at $10,000 \mathrm{rpm}$ for $10 \mathrm{~min}$ at $4^{\circ} \mathrm{C}$. The obtained enzyme solution was assayed to determine the activities of different enzymes.

Laccase (E.C. 1.10.3.2) activity was determined using the method described by Paavola et al. [18]. MnP (E.C. 1.11.1.13) activity was measured by oxidation of DMP (2, 6-dimethoxy phenol) in sodium tartrate buffer $0.1 \mathrm{M}$ (pH 4.5) in the presence of $\mathrm{H}_{2} \mathrm{O}_{2}$ and $\mathrm{MnSO}_{4}$ to coerulignone. The increase in absorbance at $469 \mathrm{~nm}$ was determined at $30^{\circ} \mathrm{C}$ and the activity was calculated using an $\varepsilon 469$ of $27,500 / \mathrm{mol} / \mathrm{cm}$ for DMP [19]. Xylanase activity was determined by measuring the release of reducing sugars from birchwood xylan $(1.0 \% \mathrm{w} / \mathrm{v})$ using the dinitrosalicylic acid method [20].

\section{Proximate and chemical composition of WS}

Dried WS samples were analyzed in triplicate for moisture, dry matter, ether extracts, crude fiber, total carbohydrates, CP, and total ash content [21]. The acid detergent fiber (ADF), neutral detergent fiber (NDF), cellulose, hemicellulose, and lignin contents were determined using the methods described by Van Soest et al. $[22,23]$. The $\mathrm{C} / \mathrm{N}$ ratios in the fermented samples were estimated using a CHNS analyzer (Elementar Vario EL III; Analysensysteme GmbH, Hanau, Germany). Percent efficiency of the solid state fermentation (SSF) process was expressed as the loss of lignin content compared to carbohydrate breakdown and calculated using the method described by Moyson and Verachtert [24]. Loss of WS components after treatment was calculated using the following formula:

$$
U 1=\left[\left(G_{0} C_{0-} G_{1} C_{1} / G_{0} C_{0}\right] \times 100\right.
$$

Where, G0 and G1 are the masses of dry substrates at the beginning and end of fermentation, respectively, and $\mathrm{C} 0$ and $\mathrm{C} 1$ are the dry weights of the components at the beginning and end of fermentation, respectively.

\section{In vitro digestion}

In vitro digestion of non-inoculated and fungal-treated WS was estimated according to the methods described by Akhter et al. [25] with some modifications. Briefly, the inoculum was prepared by mixing fresh buffalo fecal matter $(100 \mathrm{~g} / \mathrm{L})$ in pre-warmed $\left(39^{\circ} \mathrm{C}\right)$ artificial saliva containing $\mathrm{NaHCO}_{3}(9.80 \mathrm{~g}), \mathrm{Na}_{2} \mathrm{HPO}_{4} \cdot 7 \mathrm{H}_{2} \mathrm{O}(7.0 \mathrm{~g})$; $\mathrm{KCl}(0.57 \mathrm{~g}), \mathrm{NaCl}(0.47 \mathrm{~g}), \mathrm{MgSO}_{4} \cdot 7 \mathrm{H}_{2} \mathrm{O}(0.12 \mathrm{~g})$, and $1.0 \mathrm{~mL}$ of $\mathrm{CaCl}_{2}(4 \% \mathrm{w} / \mathrm{v})$. The solution was filtered through a muslin cloth and a 500-mg aliquot of the wheat straw was placed in a $50-\mathrm{mL}$ centrifuge tube and the prepared fecal suspension was added. Then, $\mathrm{CO}_{2}$ gas was flushed into the centrifuge tubes for $48 \mathrm{~h}$ in a $39^{\circ} \mathrm{C}$ water bath. The mixture contained in the centrifuge tubes was centrifuged and the supernatant was discarded. Next, $35 \mathrm{~mL}$ of acidified pepsin $(6.6 \mathrm{~g}$ in $1 \mathrm{~L}$ of $0.1 \mathrm{~mol} / \mathrm{L} \mathrm{HCl}$ ) was added to the pellet and the tubes were again incubated under similar conditions for $48 \mathrm{~h}$ and then centrifuged. The obtained pellet was filtered through tared filter paper and dried. In vitro digestion was expressed as the loss of dry matter mass during incubation under standard assay conditions.

\section{Results}

A previous study reported that the selected soil isolate, identified as Penicillium charlesii, produced $61.4 \mathrm{IU} / \mathrm{mL}$ in $54 \mathrm{~h}$ in $220 \mathrm{~L}$ of statistically optimized medium composed of (\% w/v) TA (2.0), sucrose (1.0), $\mathrm{NaNO}_{3}(1.0)$, and $\mathrm{MgSO}_{4}(0.08 ; \mathrm{pH} 5.0)$ contained in $300-\mathrm{L}$ vessel and then fed with $1.0 \%(\mathrm{w} / \mathrm{v}) \mathrm{TA}$ after $24 \mathrm{~h}$ of incubation. The tannase obtained from the fermentation broth was partially purified by ultrafiltration $(30 \mathrm{kDa})$, ammonium sulfate precipitation, and then lyophilized with a final yield of $5.8 \mathrm{IU} / \mathrm{mg}[26]$. 
Analysis of the raw WS (control) and tannase-treated WS samples (at $0.1 \% \mathrm{w} / \mathrm{w}$ of tannase concentration) revealed tannin contents of $3.6 \%$ and $1.8 \%(\mathrm{w} / \mathrm{w})$, respectively. On further increase in tannase concentration up to $0.3 \%(\mathrm{w} / \mathrm{w})$, a 1.8 -fold higher reduction in tannin content was noted compared to the results obtained at $0.1 \%$ tannase. These results clearly indicated that an increased tannase concentration resulted in a decrease in tannin content (Table 1 ). There was a very strong positive correlation $\left(R^{2}=0.999\right)$ between enhanced GA production and TA degradation (Figure 1).

After tannin removal, tannin-free WS was then subjected to SSF using Ganoderma spp. to further improve the WS composition and to analyze the various enzymes produced and substrates transformed during fungal fermentation (Figure 2).

As in the previous experiment (Table 1), an increase in tannase concentration resulted in incremental tannin degradation. But Ganoderma spp. grown on tannin-free WS showed that $0.1 \%(\mathrm{w} / \mathrm{w})$ tannase was the optimal concentration for a remarkable increase in fungusproduced lignocellulolytic enzymes. Our results also indicated that at the optimal concentration of $0.1 \%$ tannase $(w / w)$ resulted in a 1.12 -fold increase in laccase activity, a 1.06-fold increase in MnP activity, and a 1.17fold increase in xylanase activity after incubation for 10 d compared to raw untreated WS (Table 2). Along with the production of various lignocellulolytic enzymes, the Ganoderma spp. could also colonize and rapidly degrade WS, thereby showing a variation in dry matter loss (DML). A higher DML of $14.6 \%(\mathrm{w} / \mathrm{w})$ was obtained in Ganoderma grown on WS treated with $0.1 \%(\mathrm{w} / \mathrm{w})$ tannase. By further increasing the tannase concentration beyond $0.1 \%$, a decline in the lignocellulolytic activities of MnP, xylanase, and laccase along with lower DML was observed. Based on these results, we hypothesized that due to the relatively poor growth of Ganoderma, as observed at higher tannin degradation or GA concentrations; lignocellulolytic activity was decreased, indicating a reduction in lignin depolymerization.

The results of WS compositional analysis presented in Table 3 clearly showed a higher percentage of degraded lignin $(37.8 \% \mathrm{w} / \mathrm{w})$ with a lower $\mathrm{L} / \mathrm{C}$ ratio of 0.18 was obtained in the tannin-free Ganoderma-treated WS with $0.1 \%(\mathrm{w} / \mathrm{w})$ tannase. In addition, the percentage of

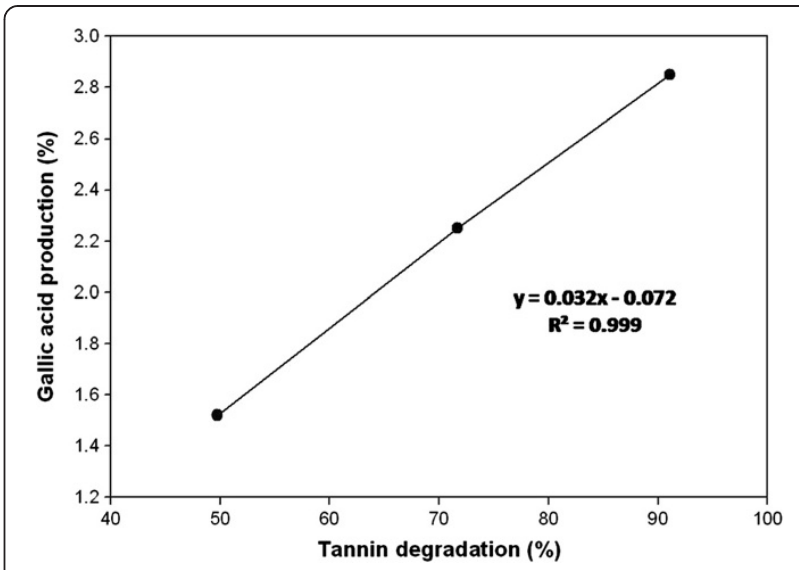

Figure 1 Positive correlation between gallic acid production and tannic acid degradation $\left(R^{2}=0.999\right)$.

degraded hemicellulose decreased to $17.9 \% \quad(\mathrm{w} / \mathrm{w})$, whereas a further increase in tannase concentration (up to $0.3 \%, \mathrm{w} / \mathrm{w})$ resulted in a lower concentration of degraded lignin $(13.0 \%, \mathrm{w} / \mathrm{w})$ with increased cellulose degradation (up to $24.5 \%, \mathrm{w} / \mathrm{w}$ ) and a higher $\mathrm{L} / \mathrm{C}$ ratio of 0.27 . Also, $32.2 \%$ of the in vitro digestibility using $0.1 \%$ tannase-treated myco-straw; therefore, $0.1 \% \quad(\mathrm{w} / \mathrm{w})$ tannase-treated myco-straw was selected, as it showed a lower $\mathrm{L} / \mathrm{C}$ ratio along with a decent percentage of in vitro digestion, which indicated improved quality of cattle feed.

Ganoderma-treated WS (myco-straw) exhibited maximum SSF efficiency (approximately 20\%) on incubation day 10. A higher SSF efficiency leads to better nutrient assimilation by fungi and a consistent increase in $\mathrm{CP}$ content. It was observed that a higher efficiency of $24.4 \%$ was obtained in tannin-free Ganoderma-treated WS $(0.1 \%$ tannase, w/w) on the 10 th day of incubation compared to the untreated control WS and 1.22-fold higher compared to myco-straw. Furthermore, the tannin-free Ganoderma-treated WS at a tannase concentration of $0.1 \%(\mathrm{w} / \mathrm{w})$ showed a 1.28 -fold higher CP content compared to myco-straw and a $25.0 \%$ lower $\mathrm{C} / \mathrm{N}$ ratio in the fermented substrate (Table 4 ).

\section{Discussion}

Worldwide energy and environmental crises have forced the re-evaluation of efficient utilization of existing resources or to find alternative natural and renewable

Table 1 Enzymatic tannin removal from wheat straw at different concentration of tannase

\begin{tabular}{lllll}
\hline Tannase concentration & Tannase activity, IU & Remaining tannin, g/100 g WS & Tannin degradation, \% & Gallic acid produced, g/100 g WS \\
\hline Raw wheat straw (control) & $0.0 \pm 0.00$ & $3.60 \pm 0.05(100 \%)$ & $0.0 \pm 0.00$ & $0.0 \pm 0.00$ \\
WS + tannase (0.1\%) & $423 \pm 11.6$ & $1.80 \pm 0.04(50.3 \%)$ & $49.7 \pm 0.99$ & $1.5 \pm 0.03$ \\
WS + tannase (0.2\%) & $846 \pm 27.5$ & $1.02 \pm 0.01(28.3 \%)$ & $71.7 \pm 1.79$ & $2.2 \pm 0.06$ \\
WS + tannase (0.3\%) & $1269 \pm 47.6$ & $0.33 \pm 0.002(8.9 \%)$ & $91.1 \pm 2.7$ & $2.8 \pm 0.09$ \\
\hline
\end{tabular}

WS $=$ wheat straw 


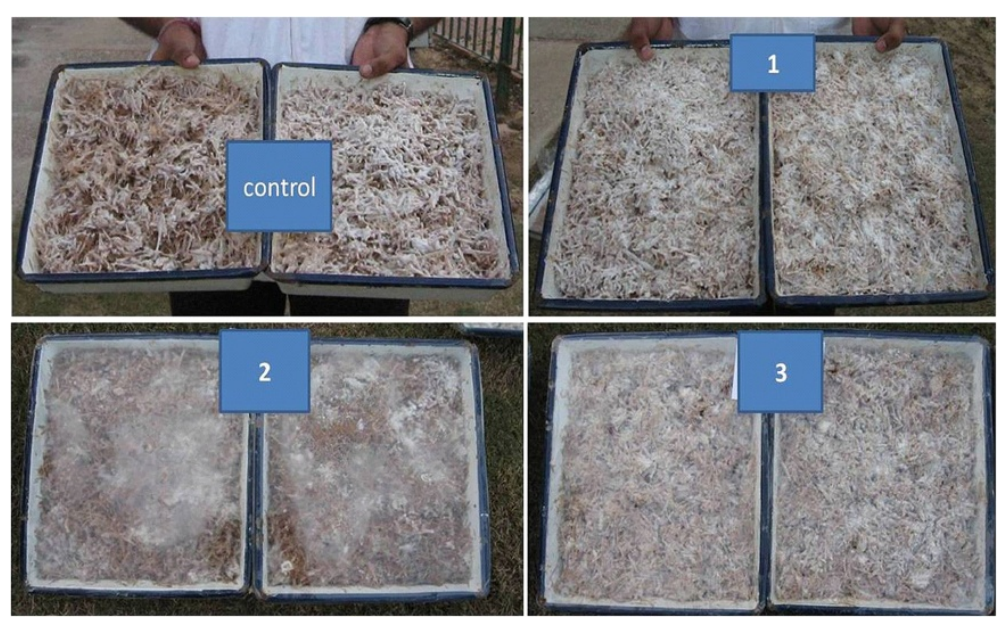

Figure 2 Growth pattern of Ganoderma sp. on raw wheat straw and tannin free ssf treated wheat straw (TFWS) Control: raw wheat straw; 1: TFWS treated with $0.1 \%$ tannase; 2 : TFWS treated with $0.2 \%$ tannase; 3 : TFWS treated with $0.3 \%$ tannase.

resources in nature, particularly to dispose of organic waste, using clean technologies. Every year, large quantities of cellulosic agriculture byproducts are being produced. In the face of global industrialization and the subsequent environmental consequences, as exemplified by the decline in forest belts and global climate changes, forces us to consider the potential benefits of finding alternative sources of cellulose. To date, WS is rarely used for cattle feed because of its relatively low nutritional value, particularly the low protein content, high fiber content, and low digestibility by ruminants. Thus, improvements in the nutrient availability in cattle feed presents a significant challenge to animal nutritionists.

The use of fungi or fungal enzymes that can metabolize lignocellulose presents a potential biological method to improve the nutritional value of WS by selective delignification [11]. The use of tannase or microbes that produce this enzyme in feed preparations increases the bioavailability of nutrients by hydrolyzing phenols, which acts as anti-nutritional factors [27]. However, due to high production costs and our limited knowledge of the catalytic activities of tannase, this enzyme is currently used under very few circumstances.

The concentration of tannins in feed plays a vital role on the digestibility by ruminants [28]. The highest tannin content showed the lowest digestibility, thus showing a strong negative correlation $(r=-0.993)$ [12].

There are several reports in the literature confirming that WS contains appreciable amounts of tannins $[29,30]$. Enhancement in the in vitro digestibility of WS up to 2.2 -fold was observed by treatment with $0.1 \%$ tannase $(\mathrm{w} / \mathrm{w})$, as well as WRF (Ganoderma sp.) under SSF, as compared to the digestibility of untreated WS. Similar to our results, Arora and Sharma [12] reported enhanced in vitro digestibility up to 1.66 -fold by WS treatment with the fungus Phlebia brevispora, obtained from northwestern and northeastern regions of India, while a 1.78-fold increase was observed by the use of fungi obtained in central India. In the present investigation, we established that the presence of $0.1 \%(\mathrm{w} / \mathrm{w})$ tannase enhanced lignin degradation as well as in vitro digestibility.

Regarding fibrolytic enzymes, several researchers have reported that the presence of aromatic compounds was required, to a certain extent, to enhance ligninase production in several WRF for lignin degradation. In the present study, it was noted that at higher tannase concentrations beyond optimal, more toxic phenolic compounds with anti-nutritional properties (tannin) were degraded up to approximately $90 \%$ with $0.3 \%(\mathrm{w} / \mathrm{w})$ tannase along with the synthesis of higher amounts of GA, which is comparably

Table 2 Enzyme production and substrate transformation during fungal fermentation of wheat straw

\begin{tabular}{llll}
\hline \multirow{2}{*}{ Tannase concentration } & \multicolumn{3}{c}{ Treated with Ganoderma sp. } \\
\cline { 2 - 4 } & Laccase, $\mathbf{U} / \mathbf{g}$ & $\mathbf{M n P}, \mathbf{U} / \mathbf{g}$ & Xylanase, U/g \\
\hline Raw wheat straw & $4012 \pm 160.4$ & $126 \pm 2.8$ & $221 \pm 6.0$ \\
WS + tannase (0.1\%) & $4518 \pm 203.3$ & $133.2 \pm 3.6$ & $260 \pm 7.8$ \\
WS + tannase (0.2\%) & $3216 \pm 120.6$ & $116 \pm 2.0$ & $210 \pm 5.2$ \\
WS + tannase (0.3\%) & $2213 \pm 60.8$ & $56.21 \pm 0.84$ & $139 \pm 2.4$ \\
\hline
\end{tabular}

WS $=$ wheat straw. 
Table 3 Disappearance (\%) of cell wall components in raw wheat straw and enzyme treated wheat straw subjected to treatment with Ganoderma sp.

\begin{tabular}{|c|c|c|c|c|c|c|c|c|c|}
\hline \multirow{2}{*}{ Substrate } & \multirow{2}{*}{$\begin{array}{l}\text { In vitro } \\
\text { digestibility,\% }\end{array}$} & \multicolumn{7}{|c|}{ \% Degradation } & \multirow{2}{*}{ L/C ratio* } \\
\hline & & $\overline{\mathrm{Wt}}$ & ADF & Lignin & Cellulose & NDF & $\mathrm{HC}$ & $\mathrm{CP}$ & \\
\hline SSF treated WS (myco- straw) & $26.8 \pm 0.8$ & $11.6 \pm 0.2$ & $17.3 \pm 0.4$ & $24.0 \pm 0.5$ & $22.6 \pm 0.6$ & $18.9 \pm 0.4$ & $21.7 \pm 0.5$ & $2.1 \pm 0.02$ & $0.23 \pm 0.003$ \\
\hline Tannin free ssf treated WS $(0.1 \%)$ & $32.2 \pm 1.1$ & $14.6 \pm 0.3$ & $20.3 \pm 0.5$ & $37.8 \pm 1.3$ & $20.4 \pm 0.4$ & $19.5 \pm 0.4$ & $17.9 \pm 0.3$ & $2.7 \pm 0.04$ & $0.18 \pm 0.001$ \\
\hline VS (0.2\%) & $27.9=$ & $12.4 \pm 0.2$ & $14.2 \pm 0.3$ & $16.6 \pm 0.3$ & $21.9 \pm 0.5$ & $19.3 \pm 0.2$ & $29.6 \pm 0.8$ & $2.14 \pm 0.03$ & $0.25 \pm 0$ \\
\hline Tannin free ssf treated WS (0.3\%) & $24.2 \pm 0.4$ & $10.9 \pm 0.1$ & $10.1 \pm 0.1$ & $13.0 \pm 0.2$ & $24.5 \pm 0.7$ & $19.6 \pm 0.3$ & $39.1 \pm 1.4$ & $2.13 \pm 0.03$ & $0.27 \pm 0.005$ \\
\hline
\end{tabular}

ADF Acid detergent fiber, NDF Neutral detergent fiber, HC Hemicellulose, CP Crude protein; * data calculated on as such basis (w/w); Uninoculated wheat straw contains in vitro digestibility of $146 \mathrm{~g} / \mathrm{kg}(14.6 \%)$.

less toxic than NA. However, this increased GA concentration could lead to lower activity of different lignocellulolytic enzymes produced from Ganoderma spp. Therefore, an optimal GA concentration is required, as GA acts as an inducer, not an inhibitor, of the lignocellulytic enzymes produced from WRF. In the present report, the amount of GA produced $(1.5 \mathrm{~g} / 100 \mathrm{~g})$ by tannin degradation with $0.1 \%(\mathrm{w} / \mathrm{w})$ tannase was sufficient to promote growth of Ganoderma spp. and to induce production of lignocellulytic enzymes. Above this concentration, GA acts as an inhibitor of the lignocellulytic enzymes laccase, and $\mathrm{MnP}$ produced by WRF, which are primarily responsible for lignin degradation through inhibition of Ganoderma growth. Our results are in accordance with those reported by Gnanamani et al. [31], in which the presence of GA at an optimal concentration of $300 \mathrm{mmol} / \mathrm{L}$ could induce activity of the lignocellulytic enzyme laccase in Phanerochaete chrysosporium (NCIM 1197). Also, Patel et al. [32] reported an increase in laccase activity of up to 1.3-fold in the presence of an optimal GA concentration. Contrary to our results, Cavallazzi et al. [33] observed no laccase activity in the presence of catechol and GA, even after $18 \mathrm{~d}$ of cultivation. The optimal GA concentration for luxurious growth and enhanced enzyme levels in WRF might produce toxic effects to ruminants by feed digestion, although the effect of toxicity will definitely be less than that induced by tannins. Lin et al. [34] postulated that produced GA can easily be assimilated by ruminants due to the sequential actions of different enzymes present in the rumen microflora to pyrogallol, phloroglucinol, and to the less toxic compounds acetate and butyrate.

In the present study, we found that by increasing the tannase concentration beyond optimal $(0.1 \%$ w/w), a greater amount of tannin was degraded and converted into GA and glucose in WS. Therefore, tannin-free Ganoderma-treated WS (beyond $0.1 \%$ w/w tannase) contains a lower tannin concentration, which is generally associated with or forms complexes with the hemicellulases of WRF, thereby leading to more free sites available for hemicellulases to degrade greater amounts of hemicellulose in WS by the actions of WRF. On compositional analysis of WS, it was observed that greater amounts of hemicellulose were degraded as compared to cellulose at higher tannase concentrations (beyond $0.1 \%$ w/w tannase). Similar results have been reported by several researchers who found that tannin-rich agromaterial can easily inhibit hemicellulases over cellulases through association, as cellulases are generally associated with the cell walls of WRF, while hemicellulases are extracellular and are, therefore, more sensitive to tannins present in lignocellulosic materials. In this respect, our results are in accordance with those reported by Hervás et al. [35], who observed increased degradation of cellulose as compared to hemicelluloses in the presence of higher residual tannins (i.e., at lower tannase concentrations).

The lignin to cellulose ratio ( $\mathrm{L} / \mathrm{C}$ ratio) is considered important for cattle feed. This ratio clearly indicates that during treatment greater quantities of lignin are degraded, thereby leaving more cellulose in the residual substrate. Therefore, enzyme-treated feed may contain more cellulose as compared to lignin in residual substrates that can be easily digested and also provides a rich source of energy to ruminants. The $\mathrm{L} / \mathrm{C}$ ratio of the tannin-free Ganoderma-treated WS was 0.18 at a tannase concentration of $0.1 \%(w / w)$. Calzada et al. [36] observed lignin degradation in the range of $24 \%$ to $55 \%$

Table 4 CP of wheat straw

\begin{tabular}{|c|c|c|c|c|c|c|}
\hline Substrate & $\mathbf{N}$ & $\mathrm{C}$ & $\mathrm{S}$ & $\mathbf{H}$ & $\mathrm{CP}$ & $\mathrm{C} / \mathrm{N}$ ratio \\
\hline SSF treated WS & $0.33 \pm 0.007$ & $36.5 \pm 1.00$ & $0.24 \pm 0.003$ & $3.83 \pm 0.07$ & $2.09 \pm 0.02$ & $109.16 \pm 3.54$ \\
\hline Tannin free ssf treated WS $(0.1 \%)$ & $0.43 \pm 0.01$ & $34.9 \pm 0.9$ & $0.48 \pm 0.007$ & $4.89 \pm 0.11$ & $2.66 \pm 0.4$ & $81.88 \pm 2.04$ \\
\hline Tannin free ssf treated WS (0.2\%) & $0.342 \pm 0.008$ & $28.7 \pm 0.5$ & $0.24 \pm 0.004$ & $3.22 \pm 0.05$ & $2.14 \pm 0.03$ & $83.80 \pm 2.30$ \\
\hline Tannin free ssf treated WS (0.3\%) & $0.341 \pm 0.008$ & $29.3 \pm 0.6$ & $0.29 \pm 0.005$ & $4.09 \pm 0.09$ & $2.13 \pm 0.03$ & $86.04 \pm 2.58$ \\
\hline
\end{tabular}

Crude Protein (CP) content in raw wheat straw: 0.56; N: nitrogen, $\mathrm{C}$ : carbon; S: sulphur; $\mathrm{H}$ : hydrogen. 
$(\mathrm{w} / \mathrm{w})$, whereas cellulose degradation ranged from $34 \%$ to $42 \%(\mathrm{w} / \mathrm{w})$ for WS inoculated with the Pleurotus spp. of WRF. Basu et al. [6] reported that the maximum desirability coefficient after incubation for $6 \mathrm{~d}$ was $19.5 \%$ $(\mathrm{w} / \mathrm{w})$ lignin and $17.8 \%(\mathrm{w} / \mathrm{w})$ cellulose degradation, although the fungus continued to degrade the substrate thereafter. Fungal fermentation using Ganoderma sp. rckk02 decreased the lignin content of WS by $34.95 \%$ $(\mathrm{w} / \mathrm{w})$ with a subsequent reduction in cellulose content by $34.33 \%(w / w)$ after incubation for $15 \mathrm{~d}$ [37].

A $78.6 \%(w / w)$ increase in CP content was observed in tannin-free Ganoderma-treated WS with $0.1 \%(\mathrm{w} / \mathrm{w})$ tannase as compared to raw WS. While, a $27.3 \%(\mathrm{w} / \mathrm{w})$ higher CP content was obtained in Ganoderma-treated WS (myco-straw). Various studies on fungal fermentation have reported the enrichment of WS with fungal biomass as the protein source under SSF [14,38]. While, Srivastava et al. [13] reported a $57.11 \%(w / w)$ increase in $\mathrm{CP}$ content by fermenting WS with Ganoderma sp. rckk02 compared to raw WS (control). The increase in CP content is partially attributable to fungal proteins, particularly chitin [38], although the observed decrease in certain cases cannot be fully explained. The $\mathrm{C} / \mathrm{N}$ ratio is an important marker of biomass pretreatment because degradation of lignocellulosic material is dependent on the $\mathrm{C} / \mathrm{N}$ ratio of the material. Deshpande et al. [39] reported that an optimal $\mathrm{C} / \mathrm{N}$ ratio promotes good fungal growth and, consequently, higher enzyme production.

It could be concluded that the use of a combination of various lignocellulytic enzymes present in WRF and tannase obtained from Penicillium charlesii resulted in complete fermentation over a short period, which indicates the scope of enriched feed production at an industrial scale. The biological treatment processes are safe, eco-friendly, easy to perform, and involves lower operational costs as compared to other treatment methods. Besides, in this process, the inoculum could be raised from existing growing cultures and reused several times to inoculate bulk amounts of residues. While, the use of chemicals is limited because once used, these substances leach into water sources, thereby requiring further treatments involving large amounts of other chemicals. If this technology could be commercialized in the future, then the enzyme tannase (lyophilized or liquid form) along with the Ganoderma sp. (dried or lyophilized form) can be made available to cattle ranchers as enriched feed at costs subsidized by the government.

\section{Competing interests}

All authors declare that they have no competing interests.

\section{Authors' contribution}

SR and SM designed and performed the experiments, including chemical analysis, collected and analyzed the data, and wrote the manuscript. RKS verified the validity of the experimentation and checked the results. All of the authors read and approved the final version of this manuscript.

\section{Acknowledgments}

This study was supported by a grant from the Council of Scientific and Industrial Research of India to S.R. (grant no.: 9/45(1190)/2012-EMR-1).

Received: 13 July 2013 Accepted: 16 February 2014

Published: 20 February 2014

\section{References}

1. Rao SVN, Ramkumar S, Natchimuthu K, Bezkorowajnyj P: Dairy cattle feeding- evidence based pro-poor institutional approach. In Proceedings of Animal Nutrition World Conference, $14^{\text {th }}$ to $17^{\text {th }}$ February, New Delhi, India. 2009.

2. Nisa MU, Sarwar M, Khan MA: Influence of ad-libitum feeding of urea treated wheat straw with or without corn steep liquor on intake, in situ digestion kinetics, nitrogen metabolism and nutrient digestion in Nilli-Ravi buffalo bulls. Aust J Agric Res 2004, 55:1-8.

3. Hanafi EM, El Khadrawy HH, Ahmed WM, Zaabal MM: Some observations on rice straw with emphasis on updates of its management. World Appl Sci J 2012, 16(3):354-361.

4. Haysa MD, Finebm PM, Eronam GCD, Kleemanc MJ, Brian K, Gulletta BK: Open burning of agricultural biomass: Physical and chemical properties of particle-phase emissions. Atmos Environ 2005, 39(36):6747-6764.

5. Castrillo C, Fondevila M, Alibes X, Joy M: Chemical treatments for upgrading lignocellulosic resources and strategies for their utilization in ruminant feeding. In Production and Utilization of lignocellulosics. Edited by Galletti GC. London: Elsevier Applied Sciences; 1991:339-313.

6. Basu S, Gaur R, Gomes J, Sreekrishnan TR, Bisaria VS: Effect of seed culture on solid state bioconversion of wheat straw by Phanerochaete chrysosporium for animal feed production. J Biosci Bioeng 2002, 1:25-30.

7. Liu JX, Orskov ER, Chen XB: Optimization of steam treatment as a method for upgrading rice straw as feeds. Anim Feed Sci Technol 1999, 76:345-357.

8. Kuhar S, Nair LM, Kuhad RC: Pretreatment of lignocellulosic material with fungi capable of higher lignin degradation and lower carbohydrate degradation improves substrate acid hydrolysis and the eventual conversion to ethanol. Can J Microbiol 2008, 54(4):305-313.

9. Okano K, Ohkoshi N, Nishiyama A, Usagawa T, Kitagawa M: Improving the nutritive value of madake bamboo, Phyllostachys bambusoides, for ruminants by culturing with the white rot fungus Ceriporiopsis subvermispora. Anim Feed Sci Technol 2009, 152:278-285.

10. Jalc D: Straw enrichment for fodder protection by fungi. In The Mycota XI Agricultural Applications. Edited by Kempken F. Berlin, Heidelberg: [C] Springer-Verlag; 2002:19-38.

11. Eriksson KEL, Blanchette RA, Ander P: Microbial and enzymatic degradation of wood and wood components. Berlin, Heidelberg, New York: Springer; 1990.

12. Arora DS, Sharma RK: Enhancement in in vitro digestibility of wheat straw obtained from different geographical regions during solid state fermentation by white rot fungi. BioResources 2009, 4:909-920.

13. Srivastava BS, Thakur S, Khasa YP, Gupte A, Puniya AK, Kuhad RC: White rot fungal conversion of wheat straw to energy rich cattle feed. Biogeosciences 2011, 22:823-831.

14. Garcýa-Conesa MT, Ostergaard P, Kauppinen S, Williamson G: Hydrolysis of diethyl diferulates by a tannase from Aspergillus oryzae. Carbohyd Polym 2001, 44(2):319-324.

15. Raghuwanshi S, Dutt K, Gupta P, Misra S, Saxena RK: Bacillus sphaericus: The highest bacterial tannase producer with potential for gallic acid synthesis. J Biosci Bioeng 2011, 111(6):635-640.

16. Deschamps AM, Otuk G, Lebeault JM: Production of tannase and degradation of chestnut tannins by bacteria. J Ferment Bioeng 1983, 61:55-59.

17. Hagerman AE, Butler LG: Protein precipitation method for quantitative determination of tannin. J Agric Food Chem 1978, 26:809-812.

18. Niku-Paavola ML, Raaska M, Itävara M: Detection of white-rot fungi by a nontoxic stain. Mycol Res 1990, 94:27-31.

19. Martinez MJ, Ruiz-Duenas FJ, Guillen F, Martinez AT: Purification and catalytic properties of two manganese peroxidase isoenzymes from Pleurotus eryngii. Eur J Biochem 1996, 237:424-432.

20. Miller GL: Use of dinitrosalicyclic acid reagent for determination of reducing sugar. Anal Chem 1959, 31:426-428.

21. AOAC: Official methods of analysis. 17th edition. Washington D.C: Association of official analytical chemists; 1995 
22. Goering HK, Van Soest PJ: Forage fiber analysis (Apparatus, reagents, procedures and some applications). In Agricultural Research Service, US Dep. Agric. Washington, DC: Agriculture Handbook; 1970:19. No. 379.

23. Van Soest PJ, Robertson JB, Lewis BA: Methods for dietary fiber, neutral detergent fiber, and non starch polysaccharides in relation to animal nutrition. J Dairy Sci 1991, 74:3583-3597.

24. Moyson $\mathrm{E}$, Verachtert $\mathrm{H}$ : Growth of higher fungi on wheat straw and their impact on the digestibility of the substrate. Appl Microbiol Biotechnol 1991, 36:42-424

25. Akhter S, Owen E, Theodorou MK, Butler EA, Minson DJ: Bovine faeces as a source of microorganisms for the invitro digestibility assay of forages. Grass Forage Sci 1999, 54:219-226.

26. Raghuwanshi S, Misra S, Saxena RK: Enzymatic treatment of black tea (CTC and Kangra orthodox) using Penicillium charlesii tannase to improve the quality of tea. J Food Process Preserv 2012, doi:10.1111/j.17454549.2012.00721.x.

27. Graminha EBN, Goncalves AZL, Pirota RDPB, Balsalobre MAA, Silva R, Gomes E: Enzyme production by solid-state fermentation: application to animal nutrition. Anim Feed Sci Technol 2008, 144(1-2):1-22.

28. McLeod MN: Plant tannins-their role in forage quality. Nutr Abstr Rev 1974, 44:803-815.

29. Patil SS, Ahmed SA, Telang SM, BAIG MMV: The nutritional value of Pleurotus ostreatus Kumm cultivated on different lignocellulosic agro wastes. Innovat Rom Food Biotechnol 2010, 7:66-76.

30. Hussain I, Uddin MB, Aziz MG: Optimization of antinutritional factors from germinated wheat and mungbean by Response Surface Methodology. Int Food Res J 2011, 18:957-963.

31. Gnanamani A, Jayaprakashvel M, Arulmani M, Sadulla S: Effect of inducers and culturing processes on laccase synthesis in Phanerochaete chrysosporium NCIM 1197 and the constitutive expression of laccase isozymes. Enzyme Microb Technol 2006, 38:1017-1021.

32. Patel H, Gupte A, Gupte S: Effect of different culture conditions and inducers on production of laccase by a basidiomycete fungal isolate Pleurotus ostreatus HP-1 under solid state fermentation. BioResources 2009, 4(1):268-284

33. Cavallazzi JRP, Kasuya CM, Soares MA: Screening of inducers for laccase production by Lentinula edodes in liquid medium. Braz J Microbiol 2005, 36:383-387.

34. Lin HV, Frassetto A, Kowalik EJ Jr, Nawrocki AR, Lu MM, Kosinski JR, Hubert JA, Szeto D, Yao X, Forrest G, Marsh DJ: Butyrate and Propionate Protect against Diet-Induced Obesity and Regulate Gut Hormones via Free Fatty Acid Receptor 3-Independent Mechanisms. PLoS One 2012, 7(4):e35240.

35. Hervás G, Frutos P, Giraldez FJ, Mantecón AR, Álvarez Del Pino MC: Effect of different doses of quebracho tannins extract on rumen fermentation in ewes. Anim Feed Sci Technol 2003, 109:65-78.

36. Calzada JF, de Leon R, de Arriola MC, Rolz C: Growth of mushrooms on wheat straw and coffee pulp: strain selection. Biol Wastes 1987, 20:217-226.

37. Srivastava B, Nandal P, Sharma A, Jain KK, Khasa YP, Das TK, Mani V, Kewalramani NJ, Kundu SS, Kuhad RC: Solid state bioconversion of wheat straw into digestible and nutritive ruminant feed by Ganoderma sp. rckk02. Bioresource Technol 2012, 107:347-351.

38. Hadar Y, Karem Z, Gorodecki B, Ardon O: Utilization of lignocellulosic waste by the edible mushroom. Pleurotus Biodegr 1992, 3:189-205.

39. Deshpande SK, Bhotmange MG, Chakrabarti T, Shastri PN: Production of cellulase and xylanase by Trichoderma reesei (QM 9414 mutant), Aspergillus niger and mixed culture by solid state fermentation (SSF) of water hyacinth (Eichhornia crassipes). Indian I Chem Technol 2008, 15:449-456.

doi:10.1186/2049-1891-5-13

Cite this article as: Raghuwanshi et al:: Treatment of wheat straw using tannase and white-rot fungus to improve feed utilization by ruminants. Journal of Animal Science and Biotechnology 2014 5:13.

\section{Submit your next manuscript to BioMed Central and take full advantage of:}

- Convenient online submission

- Thorough peer review

- No space constraints or color figure charges

- Immediate publication on acceptance

- Inclusion in PubMed, CAS, Scopus and Google Scholar

- Research which is freely available for redistribution

Submit your manuscript at www.biomedcentral.com/submit 